\title{
$\ll$ Research Note» \\ Evaluation of Commercial Phytases on Performance and Skeletal Strength of Two Broiler Strains
}

\author{
Ashley L. Shaw, John P. Blake and Edwin T. Moran, Jr. \\ Department of Poultry Science, Auburn University, Auburn, AL 36849, USA
}

\begin{abstract}
An experiment was conducted to evaluate the effects of two commercial phytases on performance and bone mineralization of male broilers from two commercial strains when included into a diet marginal in both calcium (Ca) and non-phytate phosphorus (npP). Male chicks from two broiler strains (Strains 1 and 2; 320 of each) were placed on fresh bedding across 64 pens (10 birds/pen with 8 replicates/treatment). All birds were fed a corn-soybean meal diet $(22 \% \mathrm{CP}, 3,086 \mathrm{kcal} / \mathrm{kg})$ adequate in all nutrients except $\mathrm{Ca}$ and $\mathrm{npP}$. Dietary treatments were arranged as a $2 \times 4$ factorial using $2 \mathrm{npP} / \mathrm{Ca} \mathrm{com}-$ binations and four dietary treatments: 1$)$ standard $(0.45 \% \mathrm{npP}, 1.0 \% \mathrm{Ca}), 2)$ marginal $(0.35 \% \mathrm{npP}, 0.87 \% \mathrm{Ca}), 3) \mathrm{marginal}$ +500 FTU Phytase A, and 4) marginal +500 FTU Phytase B. All diets were pelleted at $79^{\circ} \mathrm{C}$, crumbled and provided from 0 to 21 days of age. Individual body weights and feed consumption were recorded at $21 \mathrm{~d}$ of age and 24 birds per treatment were sacrificed for tibia breaking strength.

Chicks of Strain 2 were $1.7 \mathrm{~g}$ heavier $(P<0.05)$ than Strain 1 chicks at hatch, however there were no significant differences $(P>0.05)$ in body weight at $21 \mathrm{~d}$ of age. Body weight, body weight gain, feed consumption and bone strength were significantly decreased $(P<0.05)$ in the marginal diet-fed birds in comparison with the standard diet-fed birds. However, all these parameters were completely reversed with supplementation of either Phytase A or B. Overall, live performance, bone breaking strength, and response to phytase supplementation were not affected by genetic strain or type of phytase utilized in the diet. These findings suggest that reducing dietary $\mathrm{npP}$ requires phytase supplementation to obtain normal growth performance and skeletal growth, regardless of commercial broiler strain.
\end{abstract}

Key words: bone strength, broiler strain, phytase

J. Poult. Sci., 48: 47-50, 2011

\section{Introduction}

Inorganic phosphorus $(\mathrm{P})$ sources are needed in the broiler diet due to the presence of phytic acid, a natural storage form of P in many plants (NRC, 1994). As with other monogastric animals, the chicken lacks the ability to break down this molecule in large quantities, resulting in much of the bound-P being underutilized and ultimately excreted (Nahm, 2007). The high costs associated with inorganic $\mathbf{P}$ sources, which are traditionally included into a broiler diet to meet the birds' $\mathrm{P}$ requirement, has often led to the inclusion of marginal levels of $P$ in the diet. Failure to meet the birds' dietary $\mathbf{P}$ requirement can lead to reductions in performance, abnormal skeletal growth and increased mortality (Waldroup, 1999). Phytase is capable of initiating the release of the phytic acid-bound $P$ and are often included into the diet of broiler chickens, enabling inorganic $\mathbf{P}$ usage to be decreased in the diet without negatively impacting bird performance.

Received: July 9, 2010, Accepted: August 30, 2010

Released Online Advance Publication: October 25, 2010

Correspondence: A. Shaw, 201 Poultry Science, 260 Lem Morrison

Drive, Auburn, AL 36849, USA. (E-mail: hendral@auburn.edu)
Within the literature, research has lead to the suggestion that diets supplemented with phytase should be formulated with proper reductions in non-phytate phosphorus $(\mathrm{npP})$ and calcium $(\mathrm{Ca})$. Failure to reduce $\mathrm{npP}$ from standard levels in diets supplemented with phytase may result in decreased hydrolysis of the phytic acid molecule (Ballam et al., 1984; Karim, 2006) by inhibiting the catalytic activity of phytase within the digestive tract (Wise, 1983), resulting in decreased absorption of P. High dietary concentrations of $\mathrm{Ca}$ also inhibit the hydrolysis of phytate due to the formation of insoluble Ca-phytate complexes (Sands et al., 2003; Tamin et al., 2004), suggesting that phytate hydrolysis is inversely related to dietary Ca levels (Singh, 2008). Furthermore, high Ca: npP ratios suppress the absorption of inorganic soluble forms of $\mathbf{P}$ due to increased precipitation of insoluble $\mathrm{Ca}: \mathrm{P}$ complexes (Hurwitz and Bar, 1971). Thus, appropriate content of $\mathrm{Ca}$ and $\mathrm{P}$ should be included into broiler diets supplemented with phytase.

Bone strength is influenced by a number of variables. Bone density is a heritable trait in animals (Boskey et al., 1999). Williams et al. (2000a, b) have shown that continued selection for faster growth rate can result in greater 
cortical porosity and can increase the $\mathrm{Ca}$ : $\mathrm{P}$ ratio in bone mineral of broilers, resulting in weaker bones. A number of investigators have reported differences in bone strength between birds having slow and rapid growth rates (Pitsillides et al., 1999; Williams et al., 2000a), though few studies have compared commercial broiler strains. Yalcin et al. (2001) found no effect on bone strength for two commercial broiler strains beyond two weeks of age. With the exception of this study, little research has been published to show whether bone mineralization, which is directly related to bone strength, differs between commercial broiler strains.

The objective of the present study was to investigate the effects of two commercial phytases on performance and bone strength of male broilers from two different commercial strains when these two enzymes are included into a diet with appropriate reductions in $\mathrm{Ca}$ : $\mathrm{npP}$ ratio for enzyme inclusion but marginal in both calcium and $\mathrm{npP}$ according to the NRC (1994).

\section{Materials and Methods}

\section{Animals and Procedures}

A total of 640 male chicks ( 320 of each strain ${ }^{1,2}$ ) from 38 wk-old hens were obtained from a commercial hatchery, vaccinated for Marek's disease, spray vaccinated with Coccivac $\mathrm{D}^{\mathrm{TM}}$, and randomly allotted to one of eight treatment groups with 10 birds assigned to each of 64 floor pens ( 8 replicates/treatment) containing fresh pine shavings. The chicks were kept on a continuous lighting program and provided free access to feed and water throughout the trial. Individual body weights and feed consumption were recorded at $21 \mathrm{~d}$ of age and feed efficiency was calculated and corrected for mortality on a "bird-day" basis. Three birds per pen were then randomly selected for the collection of both tibiae, for a total of 48 tibias (right and left) per treatment (8 replicates/treatment). Tibia samples were stored in plastic bags and frozen at $-20^{\circ} \mathrm{C}$ until analyzed for breaking strength. Each tibia was brought to room temperature prior to assessing bone strength via a TA-HDi texture analyzer ${ }^{3}$, as described by Shaw et al. (2010). A fulcrum with a width of $3.0 \mathrm{~cm}$ supported each tibia and a round-based probe attached to a $50 \mathrm{~kg}$ load cell, with a crosshead speed of 1 $\mathrm{mm} / \mathrm{s}$, was used to break each bone. Experimentation was carried out in the facilities of the Auburn University Poultry Science Research Unit and animal handling procedures were in accordance with Auburn University's Institutional Animal Care and Use Committee (IACUC).

\section{Treatments}

The corn-soybean meal control diets (Table 1) included marginal $(0.35 \%, 0.87 \%)$ or standard $(0.45 \%, 1.0 \%)$ levels of $\mathrm{npP}$ and $\mathrm{Ca}$. All other nutrients within the diets were formulated to meet or exceed all nutrient requirements set forth by the NRC (1994). An additional two

\footnotetext{
${ }^{1}$ Strain 1: Cobb 700; Cobb-Vantress, Inc., Siloam Springs, AR

${ }^{2}$ Strain 2: Ross 708; Aviagen, Inc., Huntsville, AL

${ }^{3}$ Texture Technologies, Scarsdale, NY
}

Table 1. Ingredient and calculated analysis of broiler diets containing two levels of non-phytate phosphorus/ calcium combinations, fed from $0-21 \mathrm{~d}$ of age

\begin{tabular}{|c|c|c|}
\hline & \multicolumn{2}{|c|}{ Marginal Standard } \\
\hline Ingredients & \multicolumn{2}{|c|}{$-(\%)$} \\
\hline Ground yellow corn $(7.5 \% \mathrm{CP})$ & 55.71 & 54.67 \\
\hline Soybean meal $(48 \% \mathrm{CP})$ & 36.49 & 36.66 \\
\hline Poultry fat & 3.65 & 4.03 \\
\hline Dicalcium phosphate $(21.5 \% \mathrm{P} ; 18.5 \% \mathrm{Ca})$ & 1.17 & 1.72 \\
\hline Ground limestone $(38 \% \mathrm{Ca})$ & 1.36 & 1.30 \\
\hline Sodium chloride & 0.48 & 0.48 \\
\hline Trace-mineral premix ${ }^{1}$ & 0.25 & 0.25 \\
\hline Vitamin premix ${ }^{2}$ & 0.50 & 0.50 \\
\hline L-lysine $(98.5 \%)$ & 0.12 & 0.12 \\
\hline DL-methionine $(99.9 \%)$ & 0.27 & 0.27 \\
\hline Total & 100.00 & 100.00 \\
\hline \multicolumn{3}{|l|}{ Calculated Analysis (\%) } \\
\hline Metabolizable energy, $\mathrm{kcal} / \mathrm{kg}$ & 3086.00 & 3086.00 \\
\hline Crude protein & 22.00 & 22.00 \\
\hline Calcium & 0.87 & 1.00 \\
\hline Non-phytate phosphorus & 0.35 & 0.45 \\
\hline Sodium & 0.21 & 0.21 \\
\hline Lysine & 1.35 & 1.35 \\
\hline Methionine & 0.63 & 0.63 \\
\hline Methionine + Cystine & 0.97 & 0.97 \\
\hline
\end{tabular}

${ }^{1}$ Supplied the following per $\mathrm{kg}$ of complete feed: $125 \mathrm{mg}$ manganese; $1 \mathrm{mg}$ iodine; $55 \mathrm{mg}$ iron; $6 \mathrm{mg}$ copper; $55 \mathrm{mg}$, zinc; $0.3 \mathrm{mg}$ selenium.

${ }^{2}$ Supplied the following per $\mathrm{kg}$ of complete feed: 8,000 IU vitamin A (retinyl palmitate); 2,000 IU cholecalciferol; $8 \mathrm{IU}$ vitamin E (di-tocopheryl acetate); $2 \mathrm{mg}$ menadione; $5.5 \mathrm{mg}$ riboflavin; $13 \mathrm{mg}$ pantothenic acid; $36 \mathrm{mg}$ niacin; $500 \mathrm{mg}$ choline; $0.02 \mathrm{mg}$ vitamin $\mathrm{B}_{12} ; 5 \mathrm{mg}$ folic acid; $1 \mathrm{mg}$ thiamin; $2.2 \mathrm{mg}$ pyridoxine; $0.05 \mathrm{mg}$ biotin; $125 \mathrm{mg}$ ethoxyquin.

diets were produced to include either 500 FTU of Phytase A or 500 FTU of Phytase B into the marginal diet. All experimental diets were pelleted at $79^{\circ} \mathrm{C}$, crumbled, and provided from 0 to $21 \mathrm{~d}$ of age.

\section{Phytase Enzymes}

Both phytases utilized in this experiment were a 6phytase and were originally derived from Escherichia coli and mass-produced into Pichia pastoris and Schizosaccharomyces pombe, respectively. The $\mathrm{pH}$ for the optimal activity of each enzyme, according to their respective manufacturer, is 2.5-3.5 and 4.5-5.0 for Phytase $\mathrm{A}^{4}$ and $\mathrm{B}^{5}$, respectively.

\section{Statistical Analysis}

Statistical analyses were performed on all data using JMP software (SAS, 2005). Data were arranged in a $2 \times$ 4 factorial arrangement and were subjected to a one-way analysis of variance and means were separated by Tukey's Honestly Significant Difference procedure at a probability level of 0.05 . Analyses of percentages involving mortality were performed following transformation using arcsine of

\footnotetext{
${ }^{4}$ Optiphos; JBS United, Sheridan, IN

${ }^{5}$ Phyzyme XP; Danisco, Denmark
} 
their square root.

\section{Results}

Initial chick weight differed $(P<0.001)$ between the two genetic strains, where chicks from Strain 1 were on average $1.7 \mathrm{~g}$ lighter than Strain 2 chicks at time of placement (data not shown). By $21 \mathrm{~d}$ of age, body weights did not differ $(P>0.05)$ between the two strains.

Regardless of genetic strain, at $21 \mathrm{~d}$, the average body weight of birds fed the marginal npP-Ca diet with either Phytase A or B were heavier $(P<0.05)$ than that of birds fed the marginal npP-Ca diet with no enzyme, while average body weight of birds fed the standard diet was intermediate (Table 2). Total body weight gain from 0-21 $\mathrm{d}$ was greater $(68 \mathrm{~g}$ or more; $P<0.05$ ) for both marginal + enzyme diets as well as the standard npP-Ca diet than that of the unsupplemented marginal diet. Feed consumption was also significantly decreased $(P<0.01)$ for birds on the unsupplemented marginal diet in comparison with the standard and marginal + Phytase B diets. Despite the differences in body weight gain and feed consumption, no differences $(P>0.05)$ were detected among the dietary treatments for feed: gain. Bone breaking strength was decreased $(P<0.001)$ for birds fed the non-supplemented, marginal npP-Ca diet in comparison with the remaining three dietary treatments. No differences were detected $(P$ $>0.05$ ) for bone strength due to genetic strain or enzyme type. There were also no interactive effects between chick strain and diet for any of the main effects.

\section{Discussion}

The results indicate a $7 \%$ decrease in body weight gain between the marginal and adequate npP-Ca diets, which was expected due to the known negative implications on weight gain associated with lowering $\mathrm{P}$ levels. This difference in body weight gain was likely due to the reduction in feed consumed by birds fed the marginal diet.

Supplementation of either Phytase A or B to the marginal diet significantly increased feed consumption to the normal level. This increase led to more than a $60 \mathrm{~g}$ improvement in body weight in comparison with the unsupplemented marginal diet. In addition, supplementation with either phytase enzyme improved bone strength, suggesting that each was capable of releasing the sufficient amount of $\mathrm{npP}$ from phytate $\mathrm{P}$. These findings suggest that npP must be included into the broiler diet near levels recommended by the NRC (1994) or, if included at marginal levels, should be supplemented with a phytase enzyme to avoid reductions in performance and skeletal strength.

The two broiler strains performed equally well in terms of feed and growth performance. Previous research has yielded similar results with regard to live performance beyond two weeks of age, where differences were not detected between commercial broiler strains if all other parameters remained constant (Smith and Pesti, 1998;

Table 2. Live performance and bone breaking strength for two broiler strains fed diets with either 0.45 or $0.35 \%$ non-phytate phosphorus (npP), of which the latter may have contained a phytase source ${ }^{1}$, from $0-21$ days of age $e^{1,2}$

\begin{tabular}{|c|c|c|c|c|c|}
\hline & \multicolumn{2}{|c|}{ Day 21} & \multicolumn{3}{|c|}{ Day $0-21$} \\
\hline & $\begin{array}{c}\text { Weight } \\
(\mathrm{g})\end{array}$ & $\begin{array}{c}\text { Force } \\
(\mathrm{kg})\end{array}$ & $\begin{array}{c}\text { BWG } \\
(\mathrm{g})\end{array}$ & $\begin{array}{l}\text { FC } \\
(\mathrm{g})\end{array}$ & $\begin{array}{c}F: G \\
(g / g)\end{array}$ \\
\hline \multicolumn{6}{|l|}{ npP-Ca level } \\
\hline Standard & $783^{\mathrm{ab}}$ & $16.0^{\mathrm{a}}$ & $736^{\mathrm{ab}}$ & $1068^{\mathrm{a}}$ & 1.46 \\
\hline Marginal & $733^{b}$ & $11.5^{\mathrm{b}}$ & $685^{\mathrm{c}}$ & $984^{\mathrm{b}}$ & 1.43 \\
\hline+ Enzyme $A^{3}$ & $797^{\mathrm{a}}$ & $16.6^{\mathrm{a}}$ & $750^{\mathrm{a}}$ & $1052^{\mathrm{ab}}$ & 1.41 \\
\hline + Enzyme B & $795^{\mathrm{a}}$ & $16.0^{\mathrm{a}}$ & $748^{\mathrm{ab}}$ & $1102^{\mathrm{a}}$ & 1.48 \\
\hline$S E M^{4}$ & 17.0 & 0.70 & 16.4 & 22.4 & 0.028 \\
\hline \multicolumn{6}{|l|}{ Broiler strain } \\
\hline Strain 1 & 774 & 14.8 & 728 & 1047 & 1.44 \\
\hline \multirow[t]{3}{*}{ Strain 2} & 780 & 15.2 & 732 & 1055 & 1.45 \\
\hline & 13.0 & 0.53 & 13.0 & 15.2 & 0.023 \\
\hline & & & Significance & & \\
\hline npP-Ca level & $*$ & $* * *$ & $*$ & $* *$ & $N S$ \\
\hline Broiler strain & $N S$ & $N S$ & $N S$ & $N S$ & $N S$ \\
\hline
\end{tabular}

${ }^{1}$ All values represent contrasts involving 64 pens, each with 10 chicks at start of experimentation.

${ }^{2}$ At hatch, Strain 1 had an average body weight of $46.5 \mathrm{~g}$ and Strain 2 had an average body weight of $48.2 \mathrm{~g}$.

${ }^{3}$ Each enzyme was included into the diet at $500 \mathrm{FTU} / \mathrm{kg}$.

${ }^{4}$ SEM: Pooled standard error of the mean.

${ }^{\mathrm{a}, \mathrm{b}}$ Means with different superscripts in a column differ.

NS, $P>0.05 ; * P<0.05 ; P<0.01 ; * * * P<0.001$. 
Applegate et al., 2003; Wolanski et al., 2006). While Yalcin et al. (2001) did not provide data on live performance, results on bone strength beyond two weeks of age for multiple commercial broiler strains was not found to differ, similar to that of the current study.

There were no statistical differences for live performance between the supplementation of Phytase A or B, however Phytase A resulted in a lower feed consumption (50 g less/bird than Phytase B). This resulted in the numerically lowest FCR among all groups. The literature has previously shown that phytase not only improve the digestibility of minerals such as $\mathrm{Ca}$ and $\mathrm{P}$, but also proteins (Kornegay et al., 1996; Yi et al., 1996; Selle et al., 2000), amino acids (Kornegay et al., 1996; Yi et al., 1996; Ravindran et al., 2000), and starches (Ravindran et al., 1999) digestibilities.

Overall, neither broiler strain or phytase source was found to have an effect on bone breaking strength. Regardless of the specific source, supplementation of the marginal npP-Ca diets with phytase was found to improve live and bone performance. Therefore, decreasing dietary levels of $\mathrm{npP}$, while maintaining a $2: 1 \mathrm{Ca}$ to $\mathrm{npP}$ ratio, requires phytase supplementation to obtain normal growth performance and skeletal growth, regardless of commercial broiler strain.

\section{References}

Applegate TJ, Angel R and Classen HL. Effect of dietary calcium, 25-hydroxycholecalciferol or bird strain on small intestinal phytase activity in broiler chickens. Poultry Science, 82: 1140-1148. 2003.

Ballam GC, Nelson TS and Kirby LK. Effect of fiber and phytate source and of calcium and phosphorus level on phytate hydrolysis in the chick. Poultry Science, 63: 333-338. 1984.

Boskey AL, Wright TM and Blank RD. Collagen and bone strength. Journal of Bone Mineral Research, 14: 330-335. 1999.

Hurwitz S and Bar A. Calcium and phosphorus interrelationships in the intestine of the fowl. Journal of Nutrition, 101: 677686. 1971.

Karim A. Responses of broiler chicks to non-phytate phosphorus levels and phytase supplementation. International Journal of Poultry Science, 5: 251-254. 2006.

Kornegay ET, Ravindran V and Denbow DM. Improving phytate phosphorus availability in corn and soybean meal for broilers using microbial phytase and calculation of phosphorus equivalency values for phytase. Poultry Science, 75: 240 $-249.1996$.

Nahm KH. Efficient phosphorus utilization in poultry feeding to lessen the environmental impact of excreta. World's Poultry Science Journal, 63: 625-654. 2007.

National Research Council (NRC). Nutrient Requirements of Poultry. $9^{\text {th }}$ rev. ed. National Research Council, National Academy Press, Washington, DC. 1994.

Pitsillides AA, Rawlinson SC, Mosley JR and Lanyon LE. Bone's early responses to mechanical loading differ in distinct genetic strains of chicks: selection for enhanced growth reduced skeletal adaptability. Journal of Mineral Research, 14: 980-987. 1999.

Ravindran V, Carbahug S, Ravindran G and Bryden WL. Influence of microbial phytase on apparent ileal amino acid digestibility of feedstuffs for broilers. Poultry Science, 78: 699-706. 1999.

Ravindran V, Carbahug S, Ravindran G, Selle PH and Bryden WL. Response of broiler chickens to microbial phytase supplementation as influenced by dietary phytic acid and non-phytate phosphorus levels. II. Effects on apparent metabolizable energy, nutrient digestibility and nutrient retention. British Poultry Science, 41: 193-200. 2000.

SAS Institute Inc (SAS). JMP, the Statistical Discovery Software. Version 5.1.2. Cary, NC. 2005.

Sands JS, Ragland D, Wilcox JR and Adeola O. Relative bioavailability of phosphorus in low phytate soybean meal for broiler chicks. Canadian Journal of Animal Science, 83: 95100. 2003.

Selle PH, Ravindran V, Caldwell RA and Bryden WL. Phytate and phytase: consequences for protein utilization. Nutrition Research Reviews, 13: 255-278. 2000.

Singh PK. Significance of phytic acid and supplemental phytase in chicken nutrition: a review. World's Poultry Science, 64: 553-580. 2008.

Shaw AL, Blake JP and Moran ET. Effects of flesh attachment on bone breaking and of phosphorus concentration on performance of broilers hatched from young and old flocks. Poultry Science, 89: 295-302. 2010.

Smith ER and Pesti GM. Influence of broiler strain cross and dietary protein on the performance of broilers. Poultry Science, 77: 276-281. 1998.

Tamin NM, Angel R and Christman M. Influence of dietary calcium and phytase on phytate phosphorus hydrolyses in broiler chickens. Poultry Science, 83: 1358-1367. 2004.

Waldroup PW. Nutritional approaches to reducing phosphorus excretion by poultry. Poultry Science, 78: 683-691. 1999.

Williams B, Solomon S, Waddington D, Thorp D and Farquharson C. Skeletal development in the meat-type chicken. British Poultry Science, 41: 141-149. 2000a.

Williams B, Waddington D, Solomon S and Farquharson C. Dietary effects on bone quality and turnover, and $\mathrm{Ca}$ and $\mathrm{P}$ metabolism in chickens. Research in Veterinary Science, 69: 81-87. 2000b.

Wise A. Dietary factors determining the biological activity of phytase. Nutrition Abstracts and Reviews, 53: 791-806. 1983.

Wolanski NJ, Renema RA, Robinson FE, Carney VL and Fancher BI. Relationship between chick conformation and quality measures with early growth traits in males of eight selected pure or commercial broiler breeder strains. Poultry Science, 85: 1490-1497. 2006.

Yalcin S, Ozkan S, Coskuner E, Bilgen G, Delen Y, Kurtulmus $\mathrm{Y}$ and Tanyalcin T. Effects of strain, maternal age and sex on morphological characteristics and composition of tibial bone in broilers. British Poultry Science, 42: 184-190. 2001.

Yi Z, Kornegay ET and Denbow DM. Effect of microbial phytase on nitrogen and amino acid digestibility and nitrogen retention of turkey poults fed corn-soyabean meal diets. Poultry Science, 75: 979-900. 1996. 